\title{
軟弱地盤上における施工過程・排水性を考慮した補強土擁壁の挙動解析
}

（財）鉄道総合技術研究所 小島謙一・舘山勝

日本鉄道建設公団 青木一二三・米澤豊司・丸山修

ピート地盤など軟弱地盤上に施工された補強土擁壁においては, $1 \mathrm{~m}$ 以上もの大きな沈下が想定される. 補強土擁壁の施工は, 連続壁の場合は補強材の敷設, 土の撒きだし, 転圧を繰り返し, 最後に壁面を構築 する. また, 分割壁の場合には各層ごとに壁面を施工する. 補強土擁壁内の補強材や壁面の応力状態は, 施工の状態や補強盛土や地盤の変形などによって大きく変わる. 特に軟弱地盤の場合は地盤の変形が大き く, 壁面の構造形式や壁面の施工時期によって, 補強材や壁面の負担する応力は大きく左右される. また, 粘性土を盛土材に使用した場合, 補強材に排水性を付与するかどうかにより, 補強土擁壁の変形は異なっ てくる.

本研究は, 実現場での実測データや有限要素法により, 施工工程や壁面構造, 補強材効果の違いによる 補強土擁壁の変形の違い等について検討を行ったものである.

キーワード : 補強土擁壁, 変形, 軟弱地盤, 有限要素法, 施工

\section{Deformation Analysis of Reinforced Soil with Retaining Wall to Consider Progress of Construction and Dranage of Geosynthetics on Soft Ground}

K.Kojima and M.Tateyama : Railway Technical Research Institute

H.Aoki, T.Yonezawa and O.Maruyama : Japan Railway Public Construction

The reinforced soil with retaining wall on a soft ground is predicted to considerably settle in different modes of deformation adopted orders of construction process and characteristics of geosynthetics.

This paper describes the differences of displacement, stress conditions of retaining walls and geosynthetics in the soil by using the result of finite element analyses and measured data.

Keyword : reinforced soil with retaining wall, deformation, soft ground, finite element method, construction 


\title{
軟弱地盤上における施工過程・排水性を考慮した補強土擁壁の挙動解析
}

\author{
（財）鉄道総合技術研究所 小島謙一・舘山勝
}

日本鉄道建設公団 青木一二三・米澤豊司・丸山修

\section{1. はじめに}

ピート地盤など軟弱地盤上に施工された補強土擁壁においては, 盛土荷重により $1 \mathrm{~m}$ 以上もの大きな沈 下が想定される．補強土擁壁の施工は，連続壁の場合は補強材の敷設，土の撒きだし，転圧を繰り返し， 最後に壁面を構築する. また, 分割壁の場合には各層ごとに壁面を施工する. 補強土擁壁内の補強材や壁 面の応力状態は, 施工の状態や補強盛土や地盤の変形などによって大きく変わる. 特に軟弱地盤の場合は 地盤の変形が大きく, 壁面の構造形式や壁面の施工時期によって, 壁面や補強材の負担する応力は大きく 左右される.

本研究は, 有限要素解析を用いて, 施工工程や壁面構造の違いによる壁面や補強材の違いについて検討 を行ったものである.

\section{2. 解析対象現場概要}

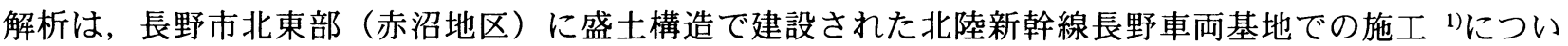
て実施した．現場は千曲川の後背湿地であり，第四紀沖積世に堆積した $30 \mathrm{~m}$ 近い軟弱な粘土層が分布し ている．図-1 に地質縱断図を示す，地層構成は，沖積粘土層（Ac), 洪積粘土層（Dc）, 洪積砂磁層（Eg） となっており, 軟弱である約 $25 \mathrm{~m}$ の沖積粘土層中には粘土質の腐植土層 $(1.7 \sim 5.2 \mathrm{~m})$ が介在しており，こ の腐植土層が短期間に多くの圧密沈下を起こすことが事前に想定された．また，本構造物は経済性を考虑 し，現場周辺で採取できる粘性土（風化凝灰岩）を採用した。そのため，間隙水圧の上昇による施工不良 に起因した盛土本体の変形についても考慮が必要 とされた.

北陸新幹線車両基地は, 新幹線車両の留置及び メンテナンスを行うものであり, 総面積約 $150,000 \mathrm{~m}^{2}$, 延長約 $1,800 \mathrm{~m}$, 最大幅約 $100 \mathrm{~m}$ の 大規模な盛土構造物である. 設計盛土高さは, $2 \mathrm{~m}$ であるが，圧密促進工法を採用し，事前にある程 度の沈下を強制的に発生させるため, 施工高さは $2.5 \mathrm{~m}$ とした. 盛土の東側のり面は将来, 北陸方 面へ新幹線が延伸されることを考慮して，1:1.5 の勾配の盛こぼしとし，西側を剛壁面補強土擁壁 工法(RRR 工法)を用いて鉛直とした，図-2 に盛 土全体の断面図, 図-3には補強土擁壁部の断面

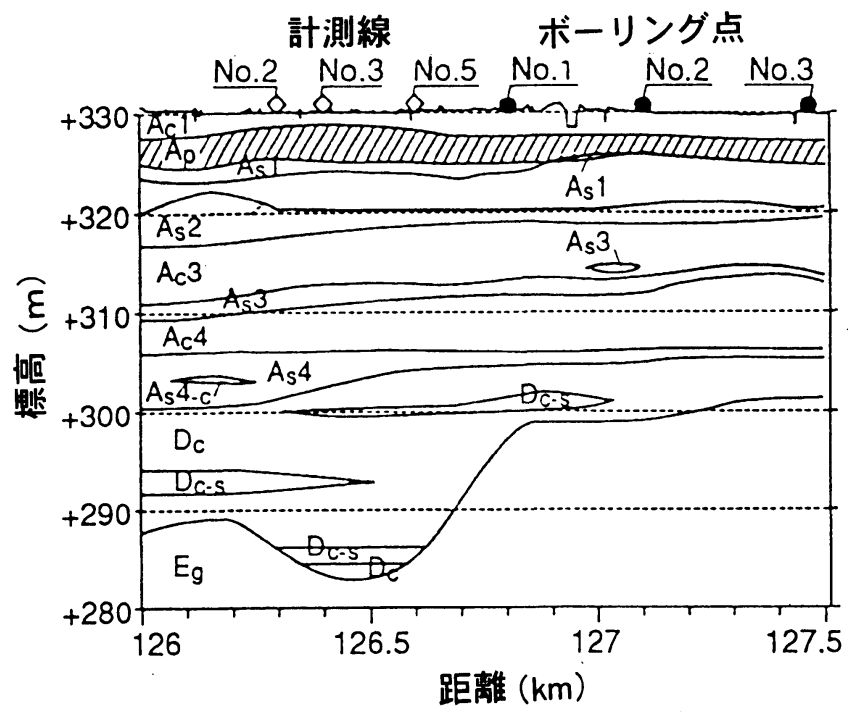

図-1 地質縦断図 
図を示す.

軟弱地盤上に盛土構造で構造物を建設する際に, 大きな問題となるのは変形である. 剛壁面補強土 擁壁工法においても，不同沈下や側方変位，これ らの変位に伴う壁面と補強材との定着切れなどが 課題となる．当現場では圧密促進工法としてプレ ロード工法を採用し，施工された補強土擁壁に高 さ $2.5 \mathrm{~m}$ のプレロード盛土を施工し， 1 年程度放 置（圧密度約 $90 \%$ 以上）を行った. その結果,

西 (剛壁面補強土搉壁)

東(のり面)

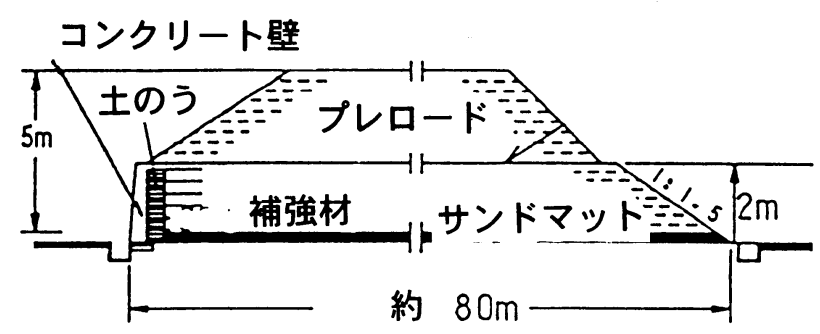

図-2 盛土断面図 盛土中央部で最大 $1.2 \mathrm{~m}$ 程度の沈下が発生した. プレロ 一ド載荷期間中, 補強土擁壁においては壁面を打設しな い状態で, 十分に盛土及び基礎地盤の変形させた後, 壁 面を打設し, 完成させた. よって，1m 以上もの沈下が 発生しても, 補強土擁壁においては有害な変形は生じな かった. 盛土材に対しては, 補強材に排水性を考慮した 複合補強材を用い, 間隙水圧の上昇を防ぎ, 十分な転圧 を可能とした.

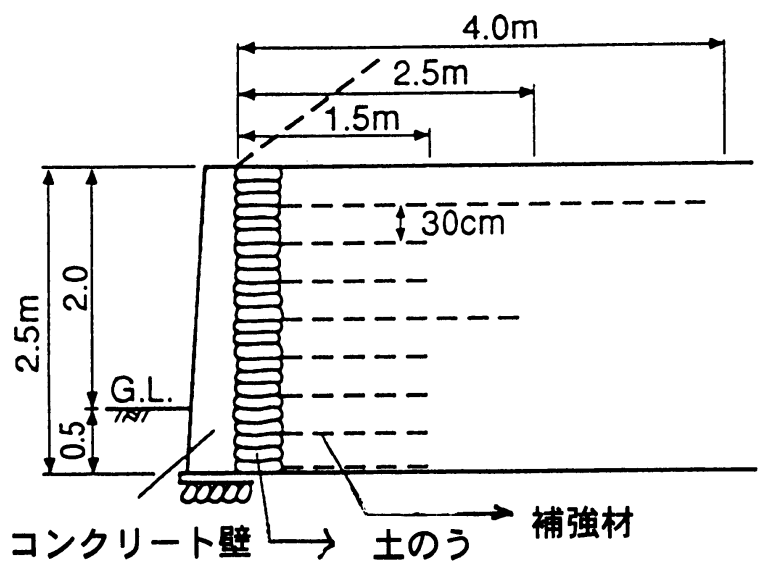

\section{3. 解析概要}

解析は壁面の補強効果及び補強材の排水性 ${ }^{2)}$ に着目して, それ ぞれ盛土の変形に対する影響を比較検討した．解析は 2 次元平面 ひずみモデルで実施した．数值解析手法としては，構成関係に関 ロ・太田モデルを組み込んだ土／水連成弾粘塑性有限要素法 (DACSAR） 3)を用いた.

\section{1 基礎地盤のモデル化}

基礎地盤は, 図-1 に示す通り約 $30 \mathrm{~m}$ の沖積粘土層が続く軟弱 地盤地帯である．解析断面には，本現場で最も多くの土質試験を 行っているエリアとし，ボーリングポイント 3 点の柱状図や土質 試験結果を基にモデル地盤を作成した. 図-4にモデル地盤の構成 を示す．本検討はモデル化を行った代表断面でのみ実施した．し かし，地盤の変形は軟弱首の厚さに大きく依存する．車両基地の 施工エリアでは腐植土層の厚さが不均一であるため, 各地点での 変形予測を行う場合には腐植土首厚を変えることが必要となる. 図-5に当現場の代表的な土質パラメータを示す.
図-3 補強土擁壁部断面図

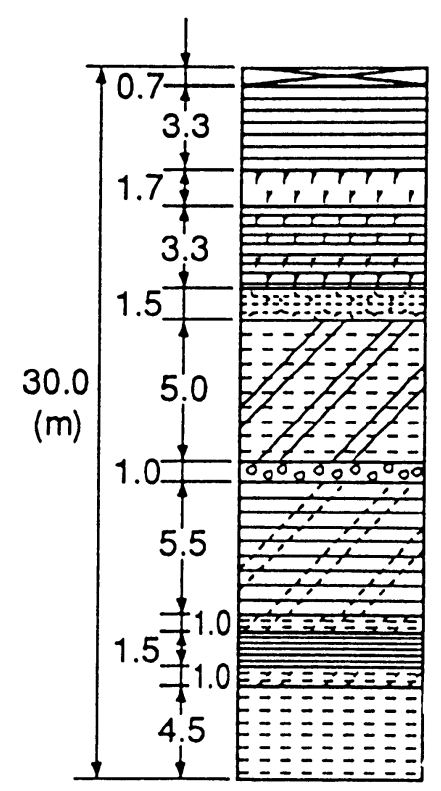

表首

粘土

席植土

腐植土まじり粘土 砂まじりシルト

粘土まじりシルト シルト ジルトまじり粘土 シルトまじり砂 粘土 シルトまじり砂 シルト 


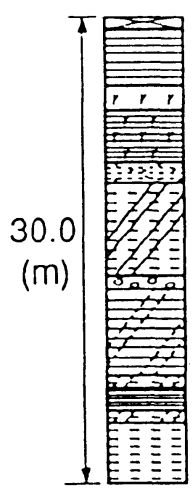

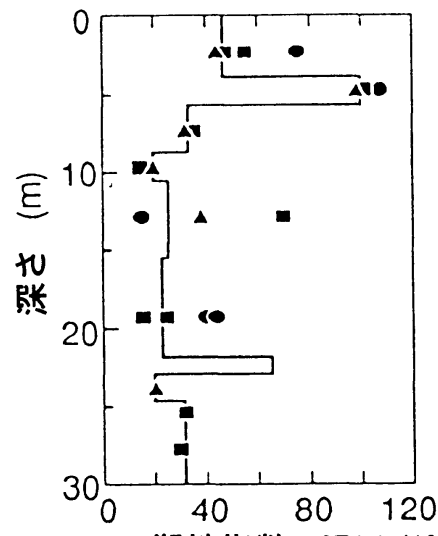

塑性指数 [PI (\%)]

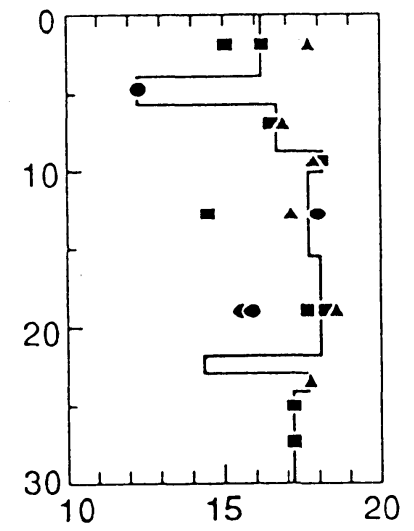

単位体積重量 $\left[\gamma_{\mathrm{f}}\left(\mathrm{kN} / \mathrm{m}^{3}\right)\right]$

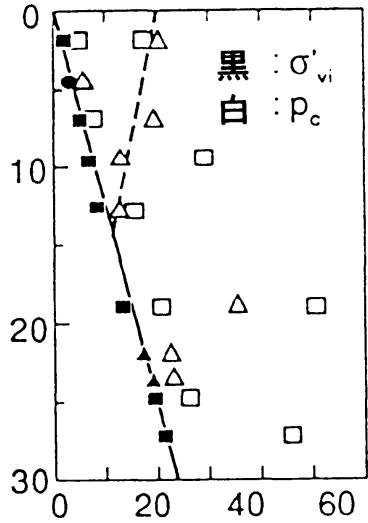

先行圧密荷重 [ $\mathrm{p}_{c}$ (MPa)] 有効上載压

ボーリング点

- : No.1

- No.2

A : No.3

図-5 主な土質パラメータ

\section{2 盛土のモデル化}

実際に施工する剛壁面補強土擁壁は，地盤の圧密沈下を考慮して高さ $2.5 \mathrm{~m}$ (計画高さ $2.0 \mathrm{~m})$ とた。盛 土幅は最大で約 $100 \mathrm{~m}$ である.このため盛土のモデル 化は, 高さ $2.5 \mathrm{~m}$, 幅は対称断面と仮定し $50 \mathrm{~m}$ とした. 基礎地盤の幅は，境界の影響を極力排除するために $250 \mathrm{~m}$ とした. 深さは $30 \mathrm{~m}$ とし，十分な支持力の得 られる層までモデル化を行った，幾何境界は底面を $\mathrm{x}$ (水平), $\mathrm{y}$ (鉛直)方向固定, 両側面では $\mathrm{x}$ 方向のみ固定 とした．排水境界は，地表面のみ排水を許した．盛土 材はシルト, 粘土分が約 $55 \%$ 有する粘性土（風化 凝灰岩）である。困-6 に本試料の粒径加積曲線を 示す。表-1に代表的な物性值を示す。解析に必要 な締固め土の特性は, 太田ら ${ }^{4)}$ の等体積一面せん断 試験を用いた締固め土の強度〜含水比〜乾燥密度の 関係を用いて主な入力パラメー夕を決定した。図-7 に一面せん断試験（圧密, せん断）結果を示す. 本 試験は, 現場での含水比が $32.5 \%$ あったため, そ の前後の 2 種類の含水比で試験を行った.この結果

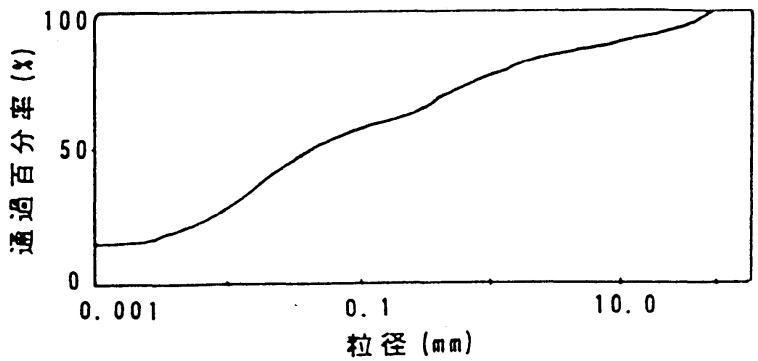

図-6 粒径加積曲線
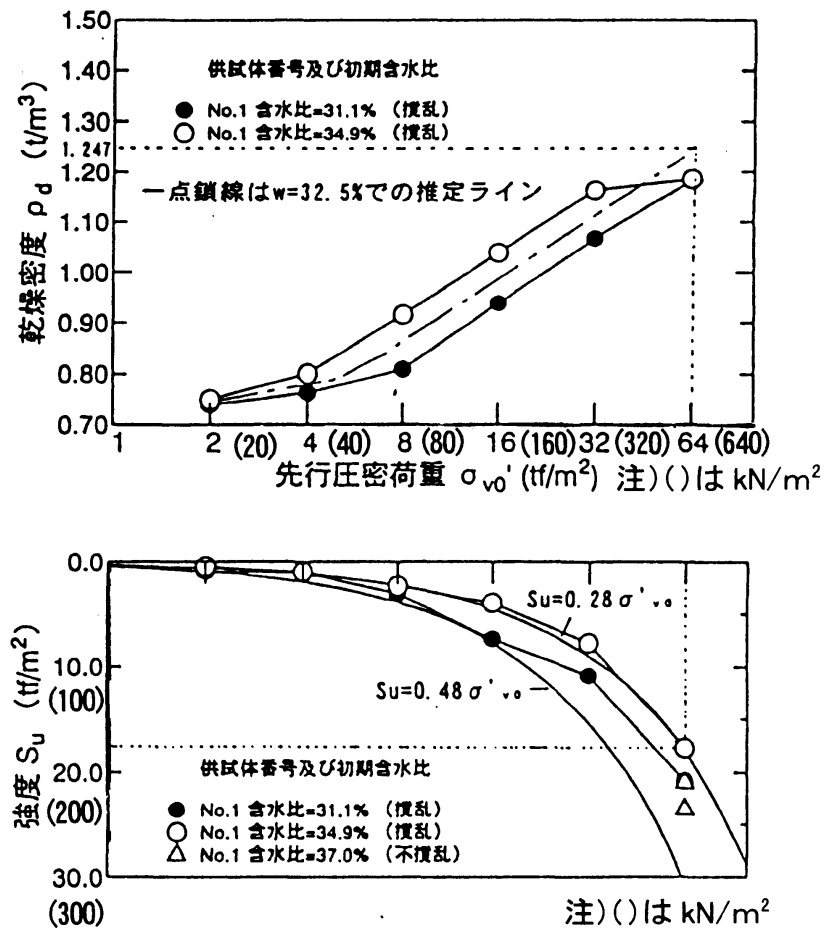

図-7一面せん断試験結果 織布と織布を複

\begin{tabular}{|c|c|}
\hline 湿潤密度 & $1.653 \mathrm{t} / \mathrm{m}^{3}$ \\
\hline 乾燥密度 & $1.247 \mathrm{t} / \mathrm{m}^{3}$ \\
\hline 塑性指数 & $29.2 \%$ \\
\hline 初期間隙比 & 1.15 \\
\hline
\end{tabular}


合したジオテキスタイルを用いている.このうち不織布は排水効果, 織布は補強効果を期待したものであ る. したがってジオテキスタイルの解析モデルにはトラス要素を用い, その部分に排水境界を設定して不 織布の排水効果を考虑した. また, 複合補強材の物性は一軸引張試験結果から求めた. ジオテキスタイル は盛土高 $0.3 \mathrm{~m}$ ごとに $1.5 \mathrm{~m}$ 敷設し, 5 層に 1 層はのり尻から内部摩擦角で引いた線までの長いジオテキ スタイルを配置している. また, 実際の補強土擁壁の構造を忠実に再現するため, 端部の要素を土のうを 模擬した弾性体とした。 土のう内は砕石であることから, 弾性体の物性を $\mathrm{N}=50$ と仮定し, $\mathrm{E}=25 \mathrm{~N}$ を用 いて変形係数を決定した. 壁面はビーム要素を用いた. 壁面の物性は, コンクリートの変形係数 $\mathrm{E}=2.5 \times$ $10^{7}\left(\mathrm{kN} / \mathrm{m}^{2}\right)$ と実際の壁厚 $0.3 \mathrm{~m}$ から算出した。

\section{3 解析ケース}

解析は, (1)壁面に関する検討, (2)補強材の排水性に関する検討について実施した. 以下に各検討項目別 の解析ケースを示す.

\subsection{1 壁面に関する検討}

壁面に関する検討は, 次に示す 2 種類の解析ケースを行った.

(a)補強土構築後, 1 週間経過させた後に壁面を打設し, 2 年間放置したケース.

(b)補強土構築後, 2 年間放置をしてから, 壁面を打設したケース.

\subsection{2 補強材の排水性に関する検討}

複合補強材の排水性がある場合とない場合の 2 ケースとし, 盛土天端 に $10 \mathrm{kN} / \mathrm{m}^{2}$ きざみで $100 \mathrm{kN} / \mathrm{m}^{2}$ まで載荷し, 排水効果について検討した. 複合補強材の排水性は, 排水境界を複合補強材配置位置に与えることで 考慮した. 補強材の排水性に関する検討においては, 効果を明確にする ため，基礎地盤を取り除いて盛土部だけで解析を実施した．解析モデル を図-8 示す.

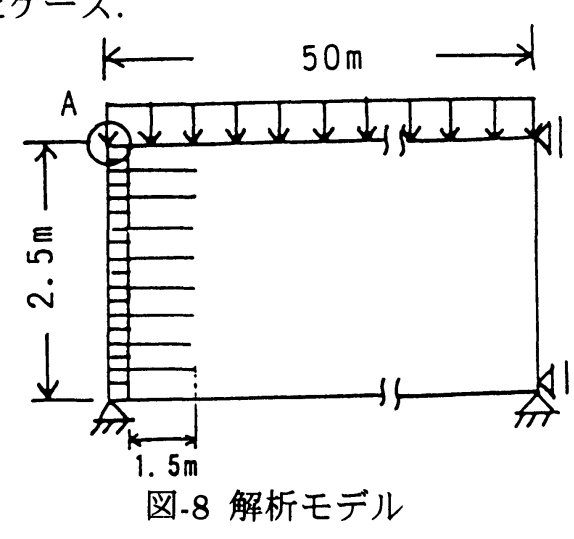

\section{4. 解析結果}

図-9に壁面を打設して放置した場合（ケ 一ス(a)）の最終状態（壁面打設後 2 年間 放置）の変形図を示す. 軟弱な基礎地盤 に影響されて盛土が変形していることが 解る. 図-10,11に 2 年間放置した後の地 表面沈下と壁面部の側方変位を示す. 沈 下をみると, 壁面のないものは約 $0.22 \mathrm{~m}$ (ケース(b)), 事前に壁面を打設したもの (ケース(a)）は最大で約 $0.16 \mathrm{~m}$ であり,

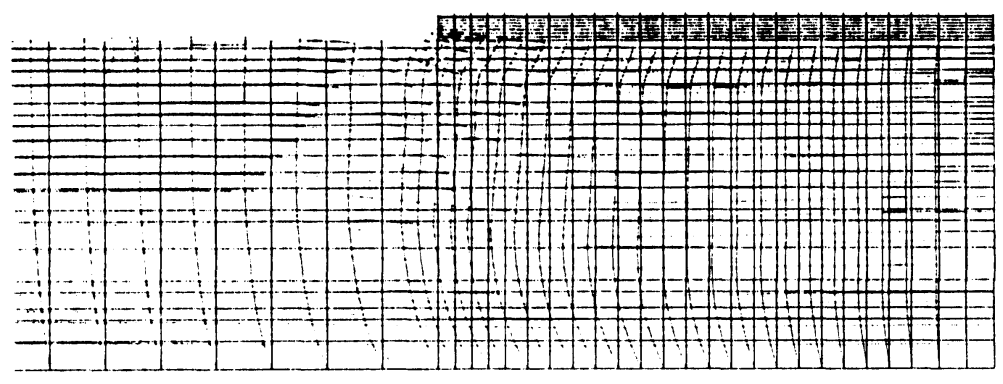

図-9 変形図 (ケース $(\mathrm{a}))$ 


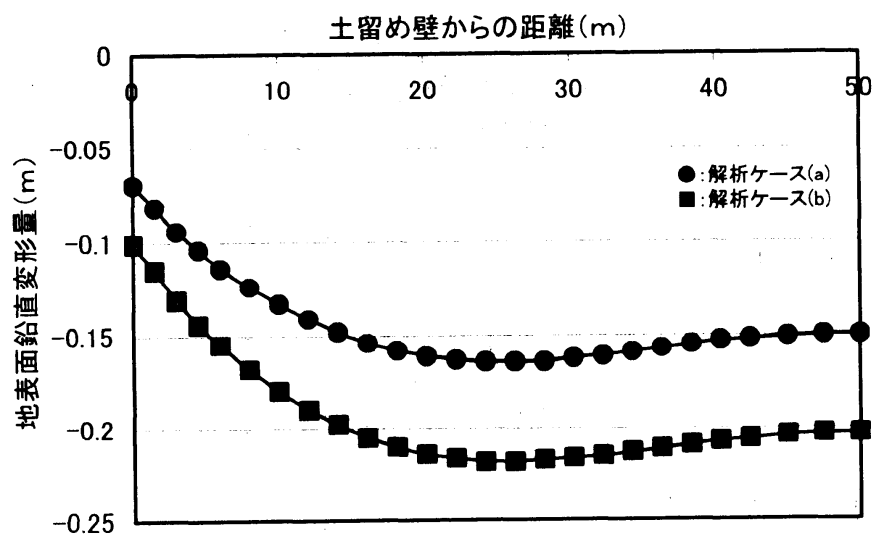

図-10 解析結果（地表面沈下量）

壁面剛性によって壁面のない場合の $70 \%$ 程度に減少し た．側方変位では壁面の有無に関わらず，基礎地盤の変 形に大きく左右されたため盛土底部付近の変形が大きく なった．壁面の有無による側方変位量の差は $0.1 \mathrm{~m}$ であ り，壁面剛性による減少率は $10 \%$ 程度であった。図-12 に補強材のひずみ分布を示す (引張り正). 今回の解析 においては，壁面付近の側方変位があまり違いがなく， 大きな沈下が発生したのが盛土中央部の補強材の入って いない領域であったため, 側方変位や補強材のひずみに 大きな差が生じなかった.

盛土頂部（図-8 ポイント A）での水平, 鉛直方向の変

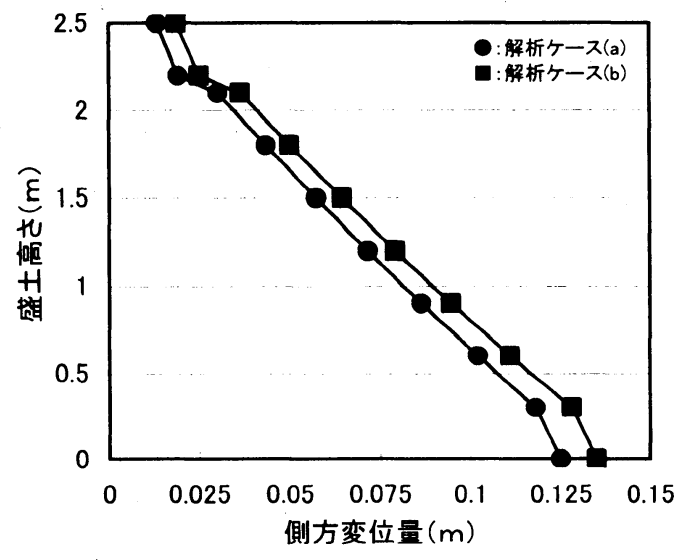

図-11 解析結果（側方変位）

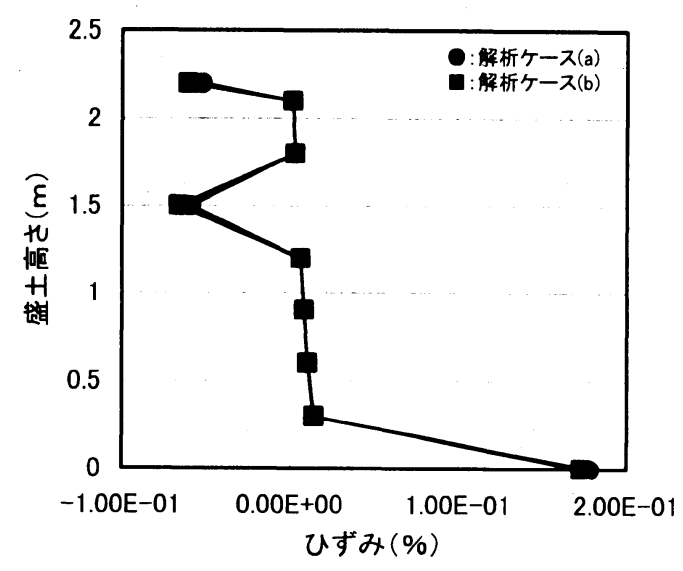

図-12 解析結果（ひずみ分布）

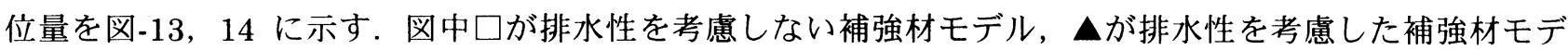
ルである. $100 \mathrm{kN} / \mathrm{m}^{2}$ 載荷時で複合補強材の排水性を考慮した場合は，考慮しない場合に比べて水平方向 で $0.1 \mathrm{~m}$, 鈶直方向で $0.05 \mathrm{~m}$ 程度, 変形量が小さくなった. しかし, 載荷重が小さい状態 $\left(10 \sim 40 \mathrm{kN} / \mathrm{m}^{2}\right.$ 程度）では有意な差が生じず, 逆に若干ではあるが排水性のある補強盛土の方が変形が大きかった. 図-15, 16 に $100 \mathrm{kN} / \mathrm{m}^{2}$ 載荷時ののり面付近の変形モードを示す. 排水性の考慮の有無で変形モードに違いは生

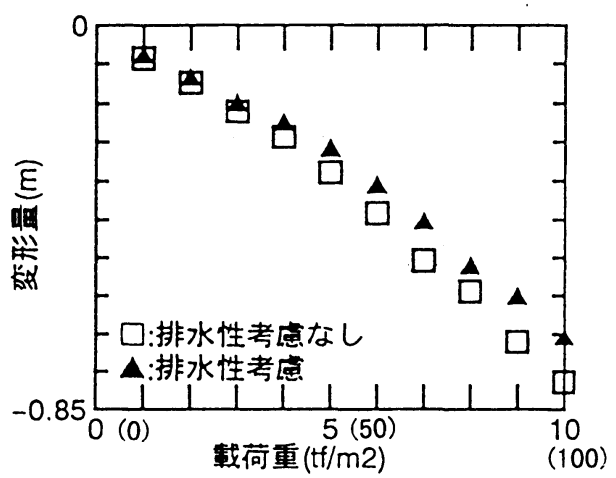

注)()は $\mathrm{kN} / \mathrm{m}^{2}$

図-13 変位量（水平方向）

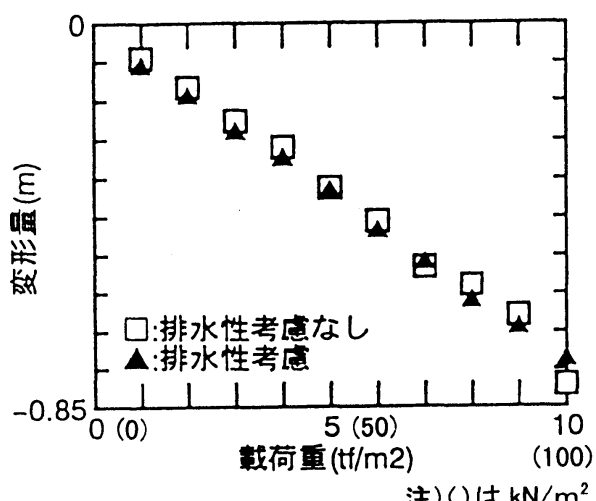

注)()は $\mathrm{kN} / \mathrm{m}^{2}$

図-14 変位量（鉛直方向）

じなかったが，排水を考慮し ない方が解放面側への倒れ込 み量がやや大きくなった.

本解析では, 載荷のみによ る排水性の検討を行ったため, 初期状態では双方差がなく， これにより載荷初期の状態で も間隙水圧の発生はあまり違 いがなかった。逆に盛土天端 の載荷と補強材の排水効果に 
よる圧密促進効果が徐々に進行して, 若干, 排水性がある補強 材の方が変形が大きくなったと考えられる. しかし, 更に載荷 が進むと盛土内の間隙水圧は補強材の配置されている上下の要 素で $3 \sim 5$ 倍程度, 補強材に接していない要素でも 1.5 倍以上 の違いが生じるようになり, その違いがのり面付近の変形量に

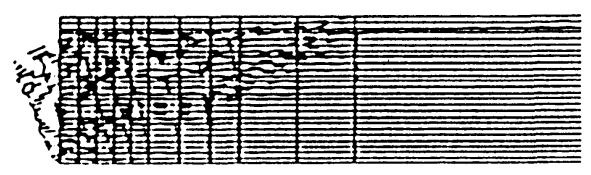

図-15＼cjkstart変形図（排水なし） 現れたものと思われる.

\section{5. まとめ}

補強土擁壁において, 非常に大きな問題となる施工過程の違 い（特に壁面の施工時期の違い）による変形特性，粘性土を盛

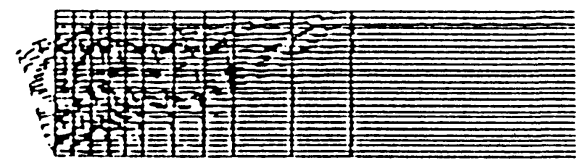

図-16 変形図（排水） 土材に用いた場合の複合補強材の排水性について, 有限要素解析を用いて検討を実施した.

壁面の施工時期の違いにおいては，基礎地盤の変形が卓越したために側方変位や補強材のひずみに大き な差が生じなかったが, 壁面がある場合の方が $10 \%$ 程度, 側方変位が減少した. また, 沈下量は, 最大沈 下量で比較すると壁面がある方が壁面のないものに対して 70\%程度の沈下量であた. このことから, 盛土 全体では壁面を設けることにより, 大きく変形量（側方, 鈶直）が変わることが解った. よって, 施工過 程の違いで, 補強土擁壁の応力状態は異なるため, 壁面の施工時期に対して十分に配虑する必要があると 考えられる，粘性土を盛土材に用いた際の複合補強材の排水性については, 間隙水圧の低減, 圧密促進, 水平変形抑制に効果を解析においても示すことが確認された.

数值解析においては, 構造部材をどのようにモテル化するのかによっても解が变わる恐れがある. 今後 は, 壁面のモデル化, 補強材のモテル化の違いについての検討を進め, より的確なモテル化の確立が必要 であると考えられる.

\section{参考文献}

1)Kojima,K, Sakamoto,N, Tateyama,M, Maruyama,O : Geosynthetic-reinforced soil retaining wall using clay on a very soft ground for Hokuriku bullet train yard in Nagano,IS-Kyushu96,1986

2)小島謙一, 館山勝: 軟弱地盤上における粘性土補強盛土の変形解析, 第 49 回年次学術講演会, 土木学 会, 1994

3)Iizuka,A, Ohta, $\mathrm{H}: \mathrm{A}$ determination procedure of input parameters in elasto-viscoplastic finite element analysis, Soil and Foundation, Vol 27, No.3,1987

4)太田秀樹，西田義親，国安，金子：土の締固め一管理基準と品質管理一，土と基礎，第 34 巻 5 号, p43 $\sim 48,1986$ 